\title{
Confirmation of a Suspected Case of Paracoccidioidomycosis Ceti by a Combination of Polymerase Chain Reaction and Loop-mediated Isothermal Amplification (PCR-LAMP) Analysis
}

\author{
Hikaru KANEGAE $^{1)}{ }^{\dagger}$, Igor Massahiro de Souza SUGUIURA ${ }^{2,4)}{ }^{\dagger}$, Tomoko MINAKAWA ${ }^{3)}$, Ono Mario AUGUSUTO ${ }^{4)}$, \\ Eiko Nakagwa ITANO ${ }^{4)}$, Shinpei WADA ${ }^{5)}$, Yuichi NAKAMURA ${ }^{1)}$, Godai SHUMOTO ${ }^{6)}$, Ayako SANO ${ }^{1,6)}$ and \\ Keiichi $\mathrm{UEDA}^{3) *}$
}

1) Faculty of Agriculture, University of the Ryukyus, Sembaru 1, Nishihara-Cho, Nakagusuku-Gun, Okinawa 903-0213, Japan

2) Paraná State Secretariat of Health Department of Health Surveillance, 17th Health Region, Alameda Miguel Blasi,

76 - Centro, Londrina - PR, 86010-070, Brazil

3) Okinawa Churashima Foundation, Aza Ishikawa 888, Motobu-Cho, Kunigami-Gun, Okinawa 905-0206, Japan

4) Department of Pathological Sciences, CCB, State University of Londrina, P.O. Box 6001, 86051-970 Londrina, PR, Brazil

5) Laboratory of Aquatic Medicine, School of Veterinary Medicine, Nippon Veterinary and Life Science University,

Kyonan-Cho 1-7-1, Musashino, Tokyo 180-8602, Japan

6) The United Graduate School of Agricultural Sciences, Kagoshima University,

1-21-24 Korimoto, Kagoshima, Kagoshima, 890-0065, Japan

[Received 13 March 2021; accepted 24 August 2021]

\begin{abstract}
Paracoccidioidomycosis ceti (PCM-C) is a zoonotic mycosis characterized by chronic granulomatous keloidal dermatitis in cetaceans that has been reported worldwide. The causative agents of PCM-C are unculturable Paracoccidioides brasiliensis var. ceti and Paracoccidioides spp., which are genetically identical to one of the causative agents of paracoccidioidomycosis: P. brasiliensis sensu stricto. The definitive diagnosis of PCM-C is based on clinical symptoms and the detection of yeast-like cells during pathological examinations; molecular diagnosis is not essential. However, analyses at the molecular level are important to distinguish PCM-C from other fungal infections showing similar clinical signs. Researchers have been following a suspected case of PCM-C in a Pacific white-sided dolphin (Lagenorhynchus obliquidens) by performing cytology, histopathology, and molecular biology experiments since 2015. Finally, we confirmed it as the fourth Japanese PCM-C case based on the partial sequence of 43-kDa glycoprotein antigen gene (gp43) with 99.4\% identity to that from P. brasiliensis sensu stricto from a biopsied sample in October 2019. Then, we applied a loop-mediated isothermal amplification (LAMP) for $P$. brasiliensis. The simple LAMP targeting for fungal DNA and human clinical materials failed to amplify bands, but a combination of polymerase chain reaction (PCR) and LAMP (PCR-LAMP) could amplify species-specific ladder-like bands identical to $P$. brasiliensis.
\end{abstract}

Key words: Diagnoses, dolphin, loop-mediated isothermal amplification (LAMP), Paracoccidioidomycosis ceti, PCRLAMP

— Jpn J Zoo Wildl Med 26(4) : 103-111, 2021

\section{INTRODUCTION}

Paracoccidioidomycosis ceti (PCM-C) is a zoonotic mycosis

$\dagger$ These authors contributed equally to the work

* Corresponding author : Keiichi UEDA(E-mail: k-ueda@okichura.jp) characterized by chronic granulomatous keloidal dermatitis in cetaceans that has been reported worldwide. The host cetacean species of PCM-C are five dolphins, namely Atlantic bottlenose dolphin (Tursiops truncatus), Indo-pacific bottlenose dolphin (T. aduncus), Pacific white-sided dolphin (Lagenorhynchus obliquidens), estuarine dolphin (Sotalia guianensis; also known 
Table 1 Follow-up examination history

\begin{tabular}{|c|c|c|c|c|c|}
\hline \multirow[t]{2}{*}{ Year } & \multicolumn{2}{|c|}{$\begin{array}{l}\text { Detection of characteristic } \\
\text { multiple-budding yeast cells }\end{array}$} & \multicolumn{3}{|c|}{$\begin{array}{c}\text { Detection of species-specific } 43 \mathrm{kDa} \text { glycoprotein } \\
\text { coding gene (gp43) }\end{array}$} \\
\hline & Cytology & Histopathology & Neted PCR & LAMP & PCR-LAMP \\
\hline $2015^{1)}$ & + & - & - & ND & $\mathrm{ND}$ \\
\hline 2016 & + & - & - & -3) & $+{ }^{3)}$ \\
\hline 2017 & + & ND & ND & ND & ND \\
\hline 2018 & $++^{2)}$ & $++^{2)}$ & - & ND & ND \\
\hline 2019 & + & + & + & - & + \\
\hline \multicolumn{6}{|c|}{$\begin{array}{l}\text { 1) The dolphin was suspected to be infected with paracoccidioidomycosis ceti diagnosed by cytology and clinical } \\
\text { characteristics in } 2015 \text { [9]. }\end{array}$} \\
\hline
\end{tabular}

as the costero dolphin), and Indian Ocean humpback dolphin (Sousa plumbea) [1].

The diagnosis for PCM-C is based on clinical symptoms, histopathologic observations, and immunologic tests by crossreaction to Paracoccidioides brasiliensisis, which is a closely related fungal species of the causative agents of PCM-C, P. brasiliensis var. ceti and Paracoccidioides spp. belonging to the order Onygenales [1]. The detection of characteristic multiple budding yeast cells during cytology or histopathology tests from the granulomatous cutaneous lesions is sufficient for diagnosing PCM-C, and molecular diagnosis is not always necessary [1]. However, it is important to differentiate PCM-C from other fungal infections caused by Trichosporon asteroids [2] and Fusarium solani [3], which develop similar cutaneous lesions and appear as yeast-like cells in infected tissues. Thus, molecular data helps in confirming the definitive diagnosis on PCM-C [1, 4, 5].

In 2018, we reported a suspected case of PCM-C based on clinical, cytological, and histopathological data [6]. Furthermore, the dolphin was also infected with Parengyodontium album, causing an opportunistic fungal infection [7]. The dolphin has been receiving annual examinations that aimed to detect a specific gene from the causative agent of PCM-C since 2015 (except in 2017), but it was not successful. However, multiple budding yeast cells were detected in biopsy tissues on each examination [6] (Table 1).

It became a modern consensus that the causative agent of PCM-C has an identical genomic profile to the P. brasiliensis S1 genotype [8], which corresponds to $P$. brasiliensis sensu stricto, a causative agent for PCM in the Latin American countries [9].
Furthermore, the specificity of the loop-mediated isothermal amplification (LAMP) method has already been confirmed for the detection of $P$. brasiliensis [10]. These findings influenced us to apply species-specific polymerase chain reaction (PCR) and/or LAMP methods for diagnosing PCM-C by targeting the gene encoding the 43-kDa glycoprotein (gp43) of $P$. brasiliensis. Despite some difficulties in detecting the targeted gene from clinical samples in human PCM using LAMP [11] and PCM-C using nested polymerase chain reactions (PCR) method [4, 5], improvements to the procedures of nested PCR, LAMP, and the combination of both methods (PCR-LAMP) are conceivable. Thus, in this study, we aimed to confirm the suspected case of PCM-C [6] using nested PCR, LAMP, and PCR-LAMP methods.

\section{MATERIALS AND METHODS}

\section{Case}

A male Pacific white-sided dolphin estimated to be 29 years old at the end of 2020 was diagnosed as a suspected case of PCM-C [6]. The dolphin has been receiving annual followup by biopsies, cytological, histopathological, and molecular biological examinations. Despite detections of the multiple budding yeast cells by cytology at every following up moment, all trials for the molecular biological diagnosis by the nested PCR method [4, 5] have failed [6] (Table 1).

In addition, Parengyodontium album was isolated from the cutaneous lesions of the dolphin in October 2018. The histopathological findings of the lesions contained fungal elements suspected and identified to be Paracoccidioides spp. and $P$. album [7]. 


\section{Samples}

Five biopsied cutaneous tissues of the granulomatous skin lesions were examined in the present study. The biopsies were performed on October 30, 2019, and samples were obtained with a $9 \mathrm{~mm}$-diameter punch. The procedures were done under infiltration anesthesia induced with lidocaine hydrochloride supplemented with $2 \%$ adrenaline (AstraZeneca K.K., Osaka, Japan) [5]. The samples were collected at the following sites: Sample number 1, lesion consisting of small papule approximately $1-2 \mathrm{~cm}$ in diameter found on the upper body and appeared in summer 2019 (image not shown); sample number 2 , lesion approximately $4 \times 7 \mathrm{~cm}$ in size found on the right side of the body (Fig. 1a); sample number 3, abundant linear granulomatous lesions without ulcers found on the upper part of the left fluke and appeared in summer 2019 (Fig 1b); sample number 4 , on the center part of the left fluke (Fig $1 \mathrm{~b})$; and number 5 , on the inner part of right fluke (no image).

\section{Cultures}

Five samples of the biopsied tissues were smeared onto CHROM-Agar Candida (Kanto Chemical Co., Inc., Tokyo, Japan), BBL Mycosel agar (Becton, Dickinson and Company [BD]; Spark, MD, USA), and potato dextrose agar (PDA; BD) plates supplemented with 100 mg/l chloramphenicol (Wako Pure Chemical Industries, Ltd. [Wako], Osaka, Japan) in duplicate (CPDA). Subsequently, the plates were incubated at $25^{\circ} \mathrm{C}$ for 2 weeks to isolate environmental or other pathogenic fungi and to rule out other potential fungal infections.

\section{Cytological and Histopathological Examinations}

The tissue samples were examined using cytological and histopathological techniques. After smearing the biopsied tissue samples onto the culture plates, they were stamped on at least 12 glass slides coated with poly L-lysine (S7441, Matsunami Glass Ind., Ltd., Osaka, Japan). Subsequently, the slide glasses were fixed with methanol (Wako) and stained with Giemsa solution (Wako).

After fixing with 70\% ethanol, the samples were embedded in paraffin by a routine method. The paraffin-embedded tissue samples were cut into $8 \mathrm{~mm}$-thick sections and stained using hematoxylin and eosin (HE), periodic acid-Schiff (PAS), and Gomori' s methenamine silver (GMS) stains.

\section{Detection of a Species-Specific Gene}

The DNA samples were extracted from paraffin-embedded tissues by DEXPAT Kit (Takara Bio, Inc., Shiga, Japan). Briefly, three $10 \mu \mathrm{m}$-thick sections of each paraffin-embedded tissue were placed into a $1.5 \mathrm{ml}$ microtube, and then $0.5 \mathrm{ml}$ of DEXPAT solution was added. After boiling the samples for 10 min, the tubes were centrifuged at $13,201 \times \mathrm{g}(12,000 \mathrm{rpm})$ for $10 \mathrm{~min}$, and the supernatants were stored as crude DNA solutions.

The five DNA samples biopsied in 2019 were purified by a routine ethanol precipitation method [7]. Then, the samples were used for gp43 amplification using nested PCR and sequencing [4, 5], LAMP for $P$. brasiliensis fungal cells with 60 min of incubation [10] and clinical materials with 120 min of incubation [10, 11], and PCR-LAMP designed in the present study. The DNA samples derived from the three previous confirmed cases of PCM-C in Japan [4, 5] were used in duplicate as positive controls. For retrospective studies, DNA samples from the tail flukes, the cotton swabs from the lesion on the right body surface and that from a ventral side of the keel extracted in August 2016, which showed negative for the detection of the partial sequence of gp43 by the nested PCR [5], were also tested and used in duplicate. In addition, two DNA samples extracted from skin swabs of a healthy false killer whale (Pseudorca crassidens) and a Pacific white-sided dolphin stored in our laboratory were used as negative controls, while the fungal DNA extracted from any P. brasiliensis isolate was not handled in the present study to avoid contamination [12]. PCR-LAMP was performed as follows: The outer speciesspecific primer set routinely used for the LAMP for detection of species-specific gp43 of P. brasiliensis (forward primer F3; 5'- TCA CGT CGC ATC TCA CAT TG-3' and reverse primer B3; 5'-AAG CGC CTT GTC CAA ATA GTC GA-3') were used for the first-round PCR with one cycle of denaturation at $95{ }^{\circ} \mathrm{C}$ for 4 min, followed by 40 cycles of amplification at $94^{\circ} \mathrm{C}$ for $1 \mathrm{~min}$, $50^{\circ} \mathrm{C}$ for $1.5 \mathrm{~min}$, and $72^{\circ} \mathrm{C}$ for $2 \mathrm{~min}$. After visualizing the amplified DNA bands using routine electrophoresis, the PCR amplicon was purified by ethanol precipitation [7] and then suspended in $25 \mathrm{ml}$ of pure water. Subsequently, instead of performing the second-round of PCR, the LAMP method was performed at $63^{\circ} \mathrm{C}$ for $120 \mathrm{~min}[10,11]$ using $1 \mathrm{ml}$ of the firstround PCR products as template. The amplified products were electrophoresed on 1.0\% agarose gels run in $1 \times$ TBE buffer (Bio-Rad Laboratories, Inc, CA, USA). 

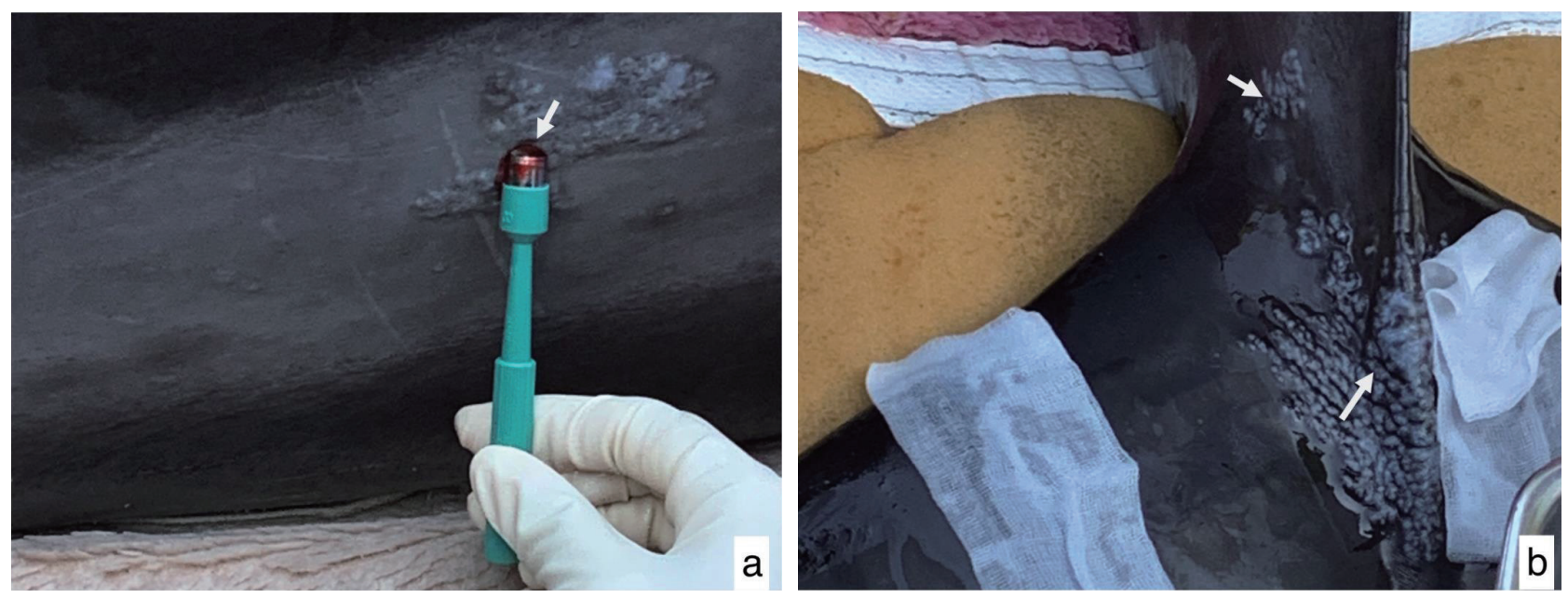

Fig. 1 Representative biopsy site from the Pacific white-sided dolphin (Lagenorhynchus obliquidens) undergoing treatment for Paracoccidioidomycosis ceti (PCM-C).

(a) The lesion on the right side of the body, approximately $4 \times 7 \mathrm{~cm}$ corresponds to the biopsied sample number 2 (arrow).

(b) Lesions consisting of abundant linear granulomatous lesions without ulcers correspond to the biopsied sample numbers 3 and 4 (upper and lower arrows) on the upperparts of the left fluke (appeared in summer 2019).

\section{RESULTS}

The biopsied skin samples cultured on CHROM-Agar Candida, BBL Mycosel agar, and CPDA were negative for pathogenic fungal species. Meanwhile, multiple budding or spherical yeast cells were detected in the smears stained with Giemsa for all five samples. The diameters of the mother cells ranged from approximately 10 to $20 \mathrm{~mm}$, whereas those of the daughter cells ranged from approximately 1 to $10 \mathrm{~mm}$ (Fig. 2a). A granulomatous lesion and a pearl-like structure were detected in a biopsied sample stained with HE (Fig. 2b). PAS(Fig. 2c) or GMS-stained samples (Fig. 2d) contained broken and/or distorted fungal elements in the pearl-like structures at the cornified keratinocyte layer, which were previously detected as fungal cells when we isolated P. album [7] (Table 1).

The first round of PCR was negative in the samples obtained from the biopsies in 2019; however, a band of approximately 400-base pairs (bps) was detected after the second round of PCR in the DNA sample derived from the left fluke lesion (Fig. 3). The confirmed partial sequence of gp43 was 378 bps long and was deposited in the GenBank database with the accession number LC537903. Moreover, a simple LAMP procedure did not amplify any band in the DNA samples, even though the reaction time was prolonged to $120 \mathrm{~min}$.

The first round of PCR using F3 and B3 primer set [10] could not amplify any DNA band in any of the DNA samples. On the other hand, one of the DNA samples derived from the Japanese PCM-C confirmed cases corresponded to the first one used as a positive control [4] showed the characteristic ladderlike DNA band pattern approximately 300, 600, 900, and over 1,000 bps in size using PCR-LAMP (Fig. 4a). One out of the five DNA samples extracted in October 2019 derived from the left fluke lesion (number 3), which contained the partial sequence of gp43 detected using nested PCR, also showed the ladderlike DNA bands amplified using PCR-LAMP (Fig. 4b). The DNAs extracted from healthy dolphins were negative for the bands. The ladder-like DNA bands also appeared in two out of five DNA samples derived from the tail fluke (Figure 4c, lane 3) and the cotton swab sample from the surface of the right body lesion (Figure 4c, lane 5) collected in August 2016, which were both negative in the detection of gp43 by the nested PCR [5] (Table 1, Fig. 4c).

The partial sequence of gp43 from the present case consisted of $378 \mathrm{bps}$, and it was detected in $P$. brasiliensis S1 cluster corresponding to P. brasiliensis sensu stricto [13], which is mainly distributed in the Latin American countries especially in Brazil, Argentina, Paraguay, Uruguay, Peru, and Venezuela $[8,14,15,16]$ via the tree view distances found with a BLAST search (http://blast.ncbi.nlm.nih.gov/) showing 99.5\% identity to P. brasiliensis sensu stricto [15]. Other 

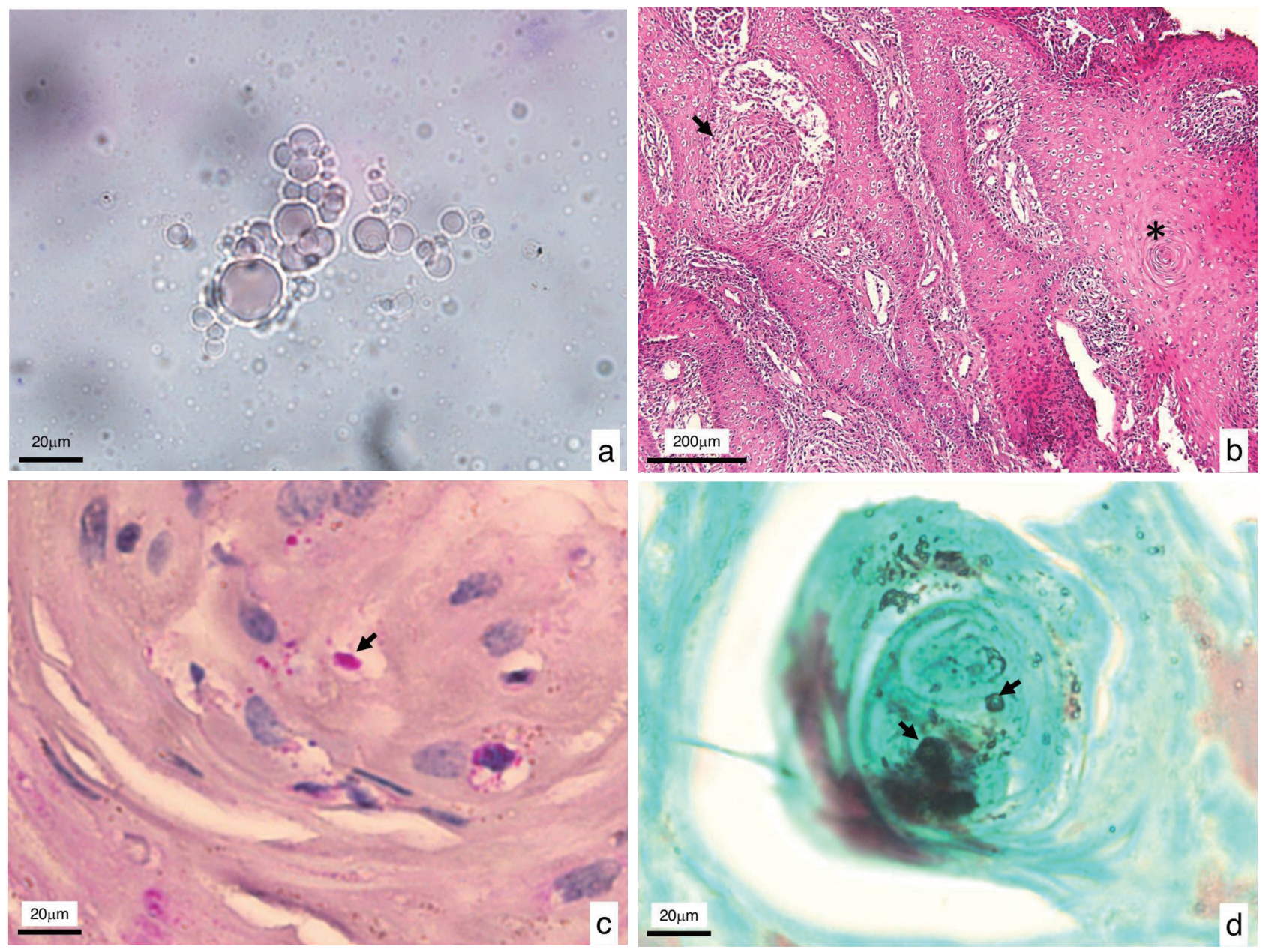

Fig. 2 Representative cytological and histopathological findings of the biopsy samples.

(a) Multiple budding yeast cells were detected in smear samples stained with Giemsa $(\times 400)$. (b) A granulomatous lesion (arrow) and a pearl-like structure $\left({ }^{*}\right)$ were detected in a biopsied sample stained with hematoxylin and eosin at a lower magnification $(\times 100)$ with a bar indicating $200 \mu \mathrm{m}$. Broken and distorted fungal elements in pearl-like structures (arrows) stained with (c) PAS $(\times 400)$ or (d) GMS $(\times 400)$. Bars indicate $20 \mu \mathrm{m}$.

representative identical sequences were AB047700 (derived from strain IFM46463 isolated from a nine-banded armadillo) $[15,17]$, AY005412 (derived from strain Pb9 isolated from a human patient), and AY005409 (derived from strain Pb14 isolated from a human patient) [18].

On the other hand, the gp43 sequence shared 96.6\% identity with gp43 detected in Paracoccidioides spp. (GenBank accession number AB811031), isolated in an Atlantic bottlenose dolphin, and were reported as the first and the second Japanese PCM-C cases [4]. Meanwhile, the gp43 sequence showed $98.8 \%$ identity with gp 43 detected in a Pacific white-sided dolphin recorded as the third PCM-C case in Japan [5]. These results present the genetic diversity of gp43 found in the causative agents of Japanese PCM-C. In addition, it was apparent that the sequence was different from those in P. luztii (GenBank accession number XM_002792442) derived from a clinical isolate in Goiania, Brazil [16]. However, these sequence data gathered are insufficient to discuss the geographical and phylogenetic diversities of gp 43 based on the gene diversities observed in other countries [1].

\section{DISCUSSION}

The present study successfully detected the partial sequence of gp43 using nested PCR in one of the five biopsy samples 


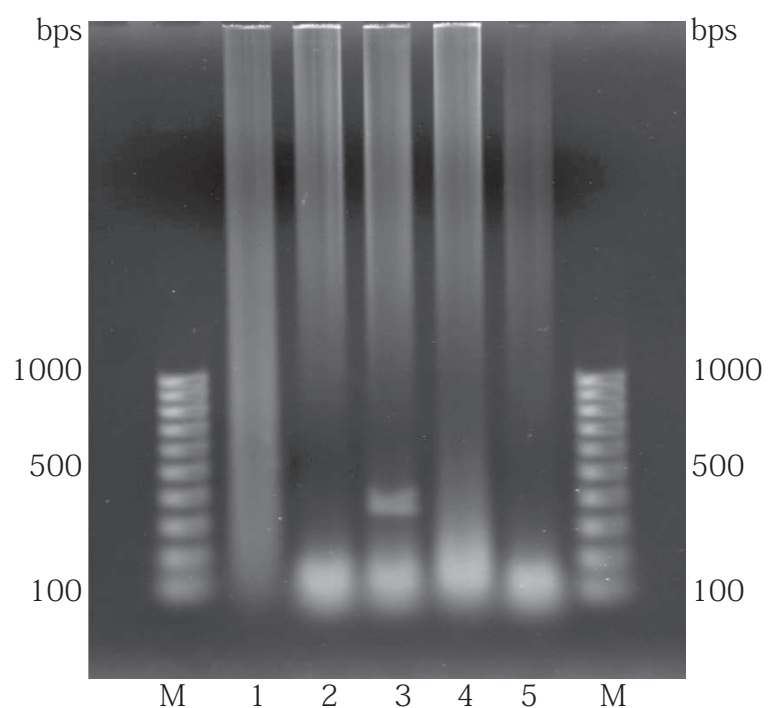

Fig. 3 Detecting gp43 by nested polymerase chain reaction. Lane 1, upper body; lane 2, right side of the body; lane 3, lower part of the left fluke; lane 4, center part of the left fluke; lane 5, inner part of the right fluke; $\mathrm{M}$, marker.

collected in October 2019. Therefore, the suspected case of PCM-C [5] was confirmed as a definitive case using molecular diagnosis techniques.

Although the dolphin has been monitored for PCM-C using nested PCR at least once a year since 2015 (except in 2017), the species-specific gene for $P$. brasiliensis was not detected. In contrast, the yeast-like cells consisting of large mother cells attached to many small daughter cells by narrow bridges were always detected during the follow-up examinations in the cytological observations, but they appeared less frequently on histopathological tissues (Table 1, Fig. 2b and c). Finally, the present study detected gp43 in the samples from 2016 and 2019 follow-up examinations using molecular diagnosis.

We failed to amplify gp43 using a simple LAMP method [10], despite prolonging the incubation time by an additional $60 \mathrm{~min}$, as done previously when detecting the gene in sputa reported by Tatibana et al. [11]. However, ladder-like bands were detected using PCR-LAMP. The pattern of the ladderlike bands was the same as that reported by Endo et al. [10]. Furthermore, the band patterns were different from those observed in P. lutzii [19]. Thus, the present case was also confirmed as PCM-C based on the genetic identities between $P$. brasiliensis sensu stricto and $P$. brasiliensis var. ceti [1] using PCR-LAMP.

According to the manufacturer's protocol for LAMP methods, gene amplification is confirmed by visual inspection of turbidity and detection of optical density under ultraviolet light (htpp://loopamp.eiken.co.jp/e/lamp/). However, if smeared amplification products are observed by agarose
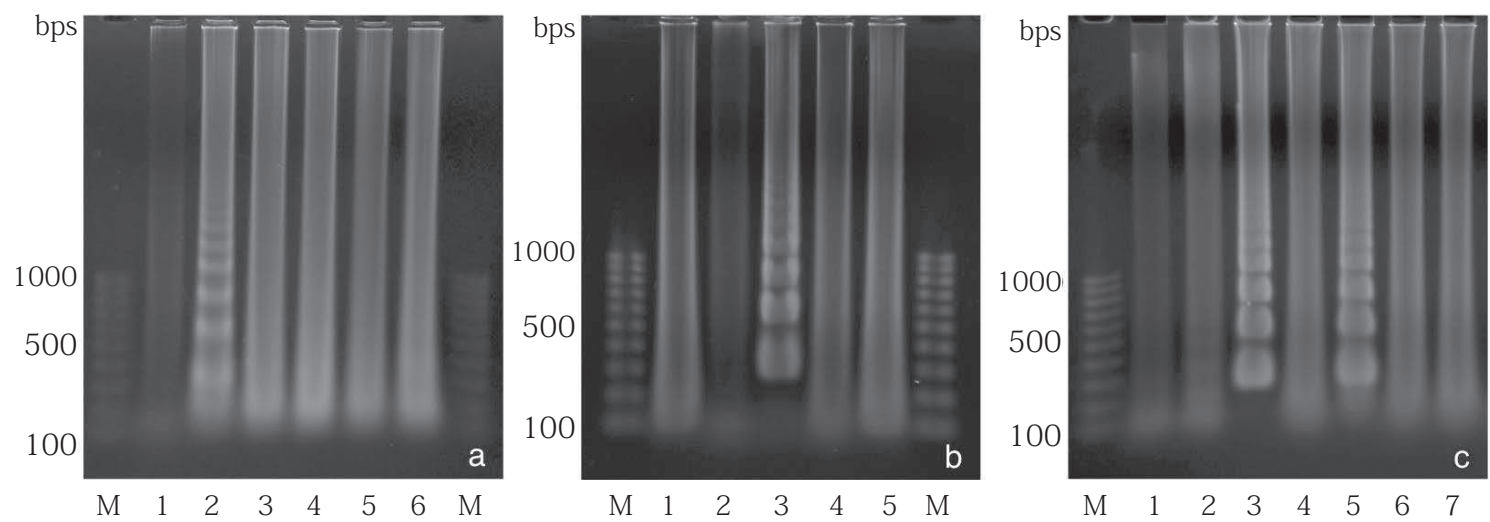

Fig. 4 Specific DNA-banding patterns for gp43 after amplification using polymerase chain reaction and loop-mediated isothermal amplification.

(a) DNA samples of the confirmed cases. Lanes 1 and 2, DNA derived from the first Japanese case; lanes 3 and 4 , those from the second one; and lanes 5 and 6, from the third ones; M, marker. (b) DNA samples extracted in 2019. Lane 1, DNA extracted from the upper body lesion; lane 2, right side of the body; lane 3, the lower part of the left fluke; lane 4, the center part of the left fluke; lane 5, inner part of the right fluke. (c) Control DNA samples and those extracted in 2016 from the present case. Lane 1, DNA extracted from skin swab of a healthy a false killer whale used as a negative control; lane 2, skin swab of a healthy Pacific whitesided dolphin used as a negative control; lanes 3 and 4, biopsies of the tail flukes: lanes 5 and 6 , the cotton swabs from a lesion at the right body surface; and lane 7 , from the ventral side of the keel. 
gel electrophoresis, false-positive results may be found as observed in the study (Fig. 4a-c). Therefore, confirmation by electrophoresis is necessary for the diagnosis [12].

Detecting gp43 using the PCR-LAMP could help in the definitive diagnosis of PCM-C without sequencing. An advantage of the combined method is that no crossreactivity with Coccidioides immitis, Histoplasma capsulatum, Blastomyces dermatitidis, Sporothrix schenckii, Talaromyces marneffei, Candida albicans, or Cryptococcus neoformans can be detected [10]. Besides, the specificity of the primers used for the first round of PCR (i.e., F3 and B3 primers) was also confirmed by Endo et al. [10]. Thus, the ladder-like bands obtained in this study were reliable. Detections of the speciesspecific gene of the causative agent of PCM-C, P. brasiliensis var. ceti, using PCR-LAMP was helpful for molecular diagnoses, but such testing should be limited outside of the endemic areas of paracoccidioidomycosis because of the possibility of environmental contamination [9].

The major disadvantage on using molecular diagnosis for the confirmation of PCM-C remains, as difficulty arises in the detection of the species-specific gene from the infected tissue samples. The partial sequence of gp43 is not always detected in previous samples even though PCR-LAMP was performed. Using both methods with repeating trials may help the molecular diagnosis techniques in confirming the suspected PCM-C cases. Moreover, the PCR-LAMP could detect gp43 from the samples that cannot be detected using nested PCR. Thus, PCR-LAMP may aid in the retrospective studies on PCM-C and may have an advantage over the nested PCR.

In conclusion, repeated trials to detect the species-specific gene is important for the appropriate diagnosis using nested PCR and PCR-LAMP. The latter technique may help with the suspected cases of PCM-C.

\section{DECLARATIONS}

FUNDING: The research was conducted based on an agreement between the University of the Ryukyus and the Okinawa Churashima Foundation. This study was partly supported by JICA (grant number 2019-S40), which was awarded to Dr. Ayako Sano and Mr. Igor Massahiro de Souza Suguiura.

CONFLICTS OF INTEREST: Not applicable

ETHICS APPROVAL: The use of cetacean samples was permitted

by the animal welfare committee of the University of the Ryukyus (approval number 2018079). All applicable international, national, and/or institutional guidelines for the care and use of animals were followed. This article does not contain any studies with human participants performed by any of the authors.

CONSENT TO PARTICIPATE: Not applicable

CONSENT FOR PUBLICATION: Not applicable

AVAILABILITY OF DATA AND MATERIAL: None

CODE AVAILABILITY: Not applicable

AUTHORS' CONTRIBUTIONS: Hikaru Kanegae and Igor Massahiro de Souza Suguiura contributed equally to this study by developing the LAMP method and PCR- LAMP method. Hikaru Kanegae also contributed by writing the manuscript. Tomoko Minakawa contributed to the clinical management. Ono Mario Augusuto contributed to the application of the LAMP method for studying PCM-C. Eiko Nakagawa Itano managed the experimental design. Shinpei Wada contributed to the clinical management and microbiological studies. Yuichi Nakamura and Godai Shumoto contributed to the immune staining (data not shown) and in writing the discussion. Ayako Sano co-supervised the project, contributed to the clinical management, and shared equal responsibilities with the corresponding author. Keiichi Ueda supervised the project and serves as the corresponding author.

ACKNOWLEDGMENT: We would like to thank Editage (www. editage.jp) for the preliminary English language editing.

\section{REFERENCES}

1. Vilela R, Mendoza L. 2018. Paracoccidioidomycosis ceti (lacaziosis/lobomycosis) in dolphins. In Emerging and Epizootic Fungal Infections in Animals (Seyedmousavi S, de Hoog GS, Guillot J, Verweij PE ed.). pp. 177-192, Springer International Publishing, Switzerland AG.

2. Ueda K, Nakamura I, Itano EN, Takemura K, Nakazato Y, Sano A. 2017. Trichosporon asteroides isolated from cutaneous lesions of a suspected case of "Paracoccidioidomycosis ceti" in a bottlenose dolphin (Tursiops truncatus). Mycopathologia 182: 937-946.

3. Tanaka M, Izawa T, Kuwamura M, Nakao T, Maezono Y, Ito S, Murata M, Murakami M, Sano A, Yamate J. 2012. Deep granulomatous dermatitis of the fin caused by Fusarium solani in a false killer whale (Pseudorca crassidens). $J$ Vet Med Sci 74: 779-782.

4. Ueda K, Sano A, Yamate J, Itano EN, Kuwamura M, Izawa T, 
Tanaka M, Hasegawa Y, Chibana H, Izumisawa Y, Miyahara H, Uchida S. 2013. Two cases of lacaziosis in bottlenose dolphins (Tursiops truncatus) in Japan. Case Rep Vet Med 2013: ID318548.

5. Minakawa T, Ueda K, Tanaka M, Tanaka N, Kuwamura M, Izawa T, Konno T, Yamate J, Itano EN, Sano A, Wada S. 2016. Detection of multiple budding yeast cells and a partial sequence of 43-kDa glycoprotein coding gene of Paracoccidioides brasiliensis from a case of lacaziosis in a female Pacific white-sided dolphin (Lagenorhynchus obliquidens). Mycopathologia 181: 523-529.

6. Minakawa T, Ueda K, Sano A, Kamisako H, Iwanaga M, Komine T, Wada S. 2018. A suspected case of Paracoccidioidomycosis ceti in a male aquarium-maintained Pacific white-sided dolphin (Lagenorhynchus obliquidens) in Japan. Jpn Zoo Wild Med 23: 45-50.

7. Kanegae H, Tomino N, Nakamura Y, Minakawa T, Yaguchi T, Izawa T, Sano A, Itano EN, Ueda K. 2020. Parengyodontium album isolated from cutaneous lesions of a Pacific whitesided dolphin (Lagenorhynchus obliquidens) during treatment for Paracoccidioidomycosis ceti. Mycopathologia 185: 1021-1031.

8. Theodoro RC, Teixeira MM, Felipe MSS, Paduan KS, Ribolla PM, San-Blas G, Bagagli E. 2012. Genus Paracoccidioides: species recognition and biogeographic aspects. PLOS ONE 7: e37694.

9. Bosco SMG, Bagagli E. 2018. 6. Paracoccidioidomycosis in animals and humans. In Emerging and Epizootic Fungal Infections in Animals (Seyedmousavi S, de Hoog GS, Guillot J, Verweij PE ed.), pp. 129-146, Springer International Publishing, Switzerland AG.

10. Endo S, Komori T, Ricci G, Sano A, Yokoyama K, Ohori A, Kamei K, Franco M, Miyaji M, Nishimura K. 2004. Detection of gp43 of Paracoccidioides brasiliensis by the loopmediated isothermal amplification (LAMP) method. FEMS Microbiol Lett 234: 93-97.

11. Tatibana BT, SanoA, Uno J, Kamei K, Igarashi T, Mikami Y, Miyaji M, Nishimura K, Itano EN. 2009. Detection of Paracoccidioides brasiliensis gp43 gene in sputa by loopmediated isothermal amplification method. J Clin Lab Anal 23: 139-143.

12. Sano A, Itano EN. 2009. Applications of loop-mediated isothermal amplification methods (LAMP) for identification and diagnosis of mycotic diseases: paracoccidioidomycosis and Ochroconis gallopava infection. In Molecular Identification of Fungi (Gherbawy Y, Voigt K ed.), pp. 417438, Springer-Verlag, Berlin.

13. Teixeira MM, Cattana ME, Matute DR, Muñoz JF, Arechavala A, Isbell K, Schipper R, Santiso G, Tracogna F, Sosa MLA, Cech N, Alvarado P, Barreto L, Chacón Y, Ortellado J, Lima CM, Chang MR, Niño-Vega G, Shikanai Yasuda MA, Felipe MSS, Negroni R, Cuomo CA, Barker B, Giusiano G. 2020. Genomic diversity of the human pathogen Paracoccidioides across the South American continent. Fungal Genet Biol 140, 103395

14. Matute DR, McEwen JG, Puccia R, Montes BA, San-Blas, G, Bagagli E, Rauscher JT, Restrepo A, Morais F, Niño-Vega G, Taylor JW. 2006. Cryptic speciation and recombination in the fungus Paracoccidioides brasiliensis as revealed by gene genealogies, Mol Biol Evol 23: 65-73.

15. Turissini DA, Gomez OM, Teixeira MM, McEwen JG, Matute DR. 2017. Species boundaries in the human pathogen Paracoccidioides. Fungal Genet Biol 106: 9-25.

16. Desjardins CA, Champion MD, Holder JW, Muszewska A, Goldberg J, Bailao AM, Brigido MM, Ferreira ME, Garcia AM, Leon-Narvaez H, Longo LV, Ma LJ, Malavazi I, Matsuo AL, Morais FV, Pereira M, Rodriguez-Brito S, Sakthikumar S, Salem-Izacc SM, Sykes SM, Teixeira MM, Vallejo MC, Walter ME, Yandava C, Young S, Zeng Q, Zucker J, Felipe MS, Goldman GH, Haas BJ, McEwen JG, Nino-Vega G, Puccia R, San-Blas G, Soares CM, Birren BW, Cuomo CA. 2011. Comparative genomic analysis of human fungal pathogens causing paracoccidioidomycosis. PLoS Genet 7: e1002354.

17. Bagagli E, Sano A, Coelho K I, Alquati S, Miyaji M, Camargo ZP, Franco., Montenegro MR. 1998. Isolation of Paracoccidioides brasiliensis from armadillos (Dasypus noveminctus) captured in an endemic area of paracoccidioidomycosis. Am J Trop Med Hyg 58: 505-512.

18. Morais FV, Barros TF, Fukada MK, Cisalpino PS, Puccia R. 2000. Polymorphism in the gene coding for the immunodominant antigen gp43 from the pathogenic fungus Paracoccidioides brasiliensis. J Clin Microbiol 38: 39603966.

19. Takayama A, Itano EN, Sano A, Ono MA, Kamei K. 2010. An atypical Paracoccidioides brasiliensis clinical isolate based on multiple gene analysis. Med Mycol 48: 64-72. 
原著論文 病理学

\title{
Polymerase chain reaction (PCR) と loop-mediated isothermal amplification (LAMP) 法の コンビネーションによるクジラ型パラコクシジオイデス症の診断法の研究
}

\author{
鐘ケ江 光 ${ }^{1) \dagger}$, Igor Massahiro de Souza SUGUIURA ${ }^{2,4)}$, 皆川智子 ${ }^{3)}$, Ono Mario AUGUSUTO ${ }^{4)}$, Eiko Nakagawa ITANO ${ }^{4)}$ \\ 和田新平 ${ }^{5)}$, 中村雄一 ${ }^{1)}$, 周本剛大 ${ }^{6)}$, 佐野文子 ${ }^{1,6)}$, 植田啓一 ${ }^{3)} *$ \\ 1) 琉球大学農学部家畜衛生学研究室 † 903-0213 沖縄県中頭郡西原町字千原 1 \\ 2) Paraná State Secretariat of Health, Department of Health Surveillance, 17th Health Region, Alameda Miguel Blasi, \\ 76 - Centro, Londrina - PR, 86010-070, Brazil \\ 3）一般財団法人沖縄美ら島財団 = 905-0206 沖縄県国頭郡本部町字石川 888 \\ 4) Department of Pathological Sciences, CCB, State University of Londrina, P.O. Box 6001, 86051-970 Londrina, PR, Brazil \\ 5）日本獣医生命科学大学水族医学研究室 $\bar{T} 180-8602$ 東京都武蔵野市境南町 1-7-1 \\ 6）鹿児島大学大学院連合農学研究科 干 890-0065 鹿児島県鹿児島市郡元 1-21-24
}

[2021 年 3 月 13 日受領, 2021 年 8 月 24 日採択 $]$

\section{要 約}

クジラ型パラコクシジオイデス症（paracoccidoioidmycosis ceti：PCM-C) は, イルカを宿主とし, 難治性慢性肉芽腫性ケロイド 状皮膚炎を特徵とする人獣共通真菌症である。原因菌は非培養性の Paracoccidioides brasiliensis var. ceti で, 中南米を流行地と する高度病原性真菌症のパラコクシジオイデス症（PCM）の原因菌 P. brasiliensis と遺伝子型は同一である。確定診断は臨床症状 と病理像での酵母細胞の証明であるが，遺伝子情報による診断も重要である。今回，遺伝子情報を欠くものの，PCM-Cが疑われ ていたイルカ皮膚病変生検組織より nested-PCR で原因菌の特異的糖タンパク抗原遺伝子である gp 43 が検出され, 配列は既報の PCM-C 国内第 3 症例目と 98.9\%相同であった。そこで PCM の診断用に設計された LAMP 法を応用したところ, PCR と LAMP 法 の組み合わせにより gp43 の増幅に成功したことから，この手法は迅速診断法としての有用性が期待できる。

キーワード : カマイルカ, クジラ型パラコクシジオイデス症, 診断, LAMP 法, paracoccidoioidomycosis ceti

* 責任著者：植田啓一（E-mail: k-ueda@okichura.jp）

$\dagger$ 共同筆頭著者 